\title{
Potential Stunting in Riverside Peoples (Study on Pahandut Urban Village, Palangka Raya City)
}

\author{
Herlina Eka Shinta ${ }^{1}$, Purnama Julia Utami ${ }^{2}$, Saputra Adiwijaya ${ }^{3}$ \\ ${ }^{1}$ Faculty of Medicine, Universitas Palangka Raya, Indonesia \\ ${ }^{2}$ Faculty of Social and Political, Universitas Palangka Raya, Indonesia \\ ${ }^{3}$ Faculty of Social and Political, Universitas Palangka Raya, Indonesia \\ herlinaekashinta.hes@gmail.com
}

\begin{abstract}
The purpose of this study was to determine the potential occurrence of stunting for residents who live on the river side, especially residents who live and inhabit the Kahayan River. And the subject is women who are pregnant, have a toddler. The study was conducted with a qualitative method, a descriptive approach used to explain stunting potential for people who live on riverside. This study uses purposive sampling, data collection techniques used: interviews, observation and documentation. The findings of this study are the environmental health conditions of people who live on riverside are very bad, if it refers to WHO standards, because there are no adequate sanitation facilities related to water management and disposal of solid and liquid waste, plus the habits of people who still throw garbage directly into the river. Environmental health in the community should be improved through collaboration of various institutions, in process to change the behavior patterns of disposing of garbage in the river. Second Findings the potential for stunting in the riverside communities is quite large, because the majority of peoples doesn't count nutritional content in food, so awareness and empowerment should be done. So that in the future there will be an increase in the quality of health of children, mothers and adolescents.
\end{abstract}

Keywords

public health, stunting, stunting roadmans

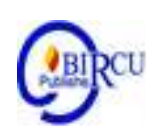

\section{Introduction}

Efforts to Increase Health Degrees in Indonesia until now have not been considered to have an Continuation of Health Development Continuation, this is when compared to neighboring Countries Health Degrees in Indonesia are still considered low. One indicator of the success of development for the development of an ideal nation is the establishment and organization of a good health system, in this discussion covering physical and psychological aspects which are added with spiritual conditions, personality and empowerment. This aspect discusses the discussion space on health development which is interrelated with other aspects.

The current global challenges also revise the health system in Indonesia. From this condition, supporting health development is carried out with the support of a good system and human resources equipped with technological support. In the ideal level that outcomes as a desire in the desired health development efforts, so that from this context sustainability will continue to exist. In the formulation made by WHO provides an understanding that the health system (health system) is all activities that have the aim to improve, improve or care 
for health. This concept then developed into a health care system because it deals with various policies made by each country. Health care system because it deals with various policies made by each country. By Lassey (1976) in (Adisasmito, 2007) states that the health care system is a combination of health institutions, supporting human resources, financial mechanisms, information systems, organizational network mechanisms, and management structures including administration, in its efforts to support the provision of health care services for patients .

One of the urgent things to do in Indonesia in aligning health development in order to reach a high degree of health is the problem of stunting. In this connection health development has an integral meaning in relation to the development of human resources in realizing an advanced and independent nation and in physical and spiritual well-being.

According to the Health Data and Information Window Bulletin (Sakti, Eka Satriani, 2018) stunting is a major nutritional problem facing Indonesia. Stunting itself is a condition of children having a length or height that is less when compared to age. In another section (Trihono, 2015) states that the stunting condition can be measured based on Zscore values $\geq-$ 3 to $<-2$ SD (short) and <-3 SD (very short) according to WHO (World Health Organization) standards. Stunting can also be interpreted as a condition of failure to thrive in children under five due to chronic malnutrition, especially in the First 1000 Days of Life (HPK). In another part of the stunting rate in Indonesia, based on basic health research data (Balitbang Kemenkes RI, 2018) in 2013, there were $37.2 \%$ of children under five who experienced stunting and decreased in 2018 to $30.8 \%$, amounting to $6.4 \%$. This figure ranks Indonesia 108th out of 132 countries included in countries with high stunting rates according to data from the 2016 Global Nutrition Report. Whereas for Central Kalimantan itself, it ranks 5th highest stunting incidence rate according to Riskedas data (Balitbang Kemenkes RI, 2018 ), with East Barito as a district included in the list of 100 priority cities / regencies of intervention with 2017 stunting children referring to the results of the 2013 RISKESDAS where $54.84 \%$ of children under five in East Barito District experienced stunting.

Meanwhile in Republika's online media reporting (Republika, 2019) the condition of stunting in Central Kalimantan is actually not only in East Barito District, but there are other regencies with high stunting levels, namely Kapuas Regency and East Kotawaringin Regency. This condition can be said as a threat in the process of building a nation, in the past the state of stunting in Indonesia has received less attention, but over time and the various cases that were revealed turned out to be a major threat to the Indonesian nation.

At the national level, representation related to environmental health vulnerability for people living on the riverside community of the river can be seen from its relationship with water quality, sanitation and hygiene based on existing geographical aspects, for example in Central Kalimantan Province. For the condition of the province of Central Kalimantan (Response, 2019) has a unique geographical characteristic because it has 11 (eleven) large rivers and no less than 33 small rivers / creeks and on average the rivers and creeks are inhabited by people who live and have activities around it, it is no wonder that actually Dayak people or migrants are people who are still dependent on the river. This can be seen that the people in Central Kalimantan Province live in lanting (floating houses) as a way to live part of the community on the riverside community of the river as a form of local wisdom that has been hereditary in Central Kalimantan.

Communities use rivers to build settlements, on the other hand some rivers in Central Kalimantan are also places for disposal of waste from human activities such as industrial waste, household waste, even human waste or feces that are discharged directly into water 
bodies because the latrines of floating riverside community do not have facilities (septic tanks).

Data on the number of residents who live on the riverside community of the river in each Regency / City in Central Kalimantan amounted to 860,426 people, and specifically for the City of Palangka Raya as many as 37,816 people (BPS, 2018). Types and number of buildings on the edge of the Kahayan Palangka Raya River, with the type of building on 452 lanting houses, 623 houses on stilts, bath,wash, toilet facilities (Jamban lanting) 245. With a total population of kahayan riverside community in the city of Palangkaraya in Pahandut Village 6,224 people and Pahandut Village across 1,636 people with a total population of 7,860 people has a job (Observation Results of Unpar Civil Engineering Students 2015, unpublished). Especially for the city of Palangka Raya, the condition of children under five who experience stunting can be said to be invisible, but that does not mean that they are free from threats to be free from stunting. There are many factors in seeing the condition of children who experience stunting, one of which is the environment. The condition of the people in the city of Palangka Raya who still live on the riverside community of the river are considered to have the potential for stunting. This is also compounded by the low understanding of the people living on the riverside community of the river on environmental cleanliness.

This condition requires a study of the potential for stunting for people who live on the riverside community of the Kahayan river, so that by knowing the potential that can cause stunting children can provide a policy strategy in handling stunting for people who live on the riverside community of the Kahayan river.

The formulation of the problem to be answered in this study is

1) What is the health condition of the people who live on the riverside community of the Kahayan river?

2) What is the potential for stunting for people living on the riverside community of the Kahayan river?

\section{Review of Literature}

\subsection{Prior Research}

In developing this research, then to provide a different perspective from previous studies, can be seen in the following research:

a. (Besral, 2014) Nutrition, Environmental Sanitation, and Utilization of Posyandu with Stunting in Toddlers in Indonesia (Riskesdas Data Analysis in 2010). The study design used was cross-sectional with a quantitative approach. This study uses Riskesdas secondary data for 2010. Independent Variables: Nutrition, Environmental Sanitation, and Posyandu Utilization. Bound Variable: Stunting Event. The results of this study indicate that factors related to the incidence of stunting, families with access to protected water sources by $33.3 \%$ protected and unprotected water sources by $39.1 \%$, latrines used at $32.7 \%$, and also families with latrines feasible and improper by $38.4 \%$, controlled by the child's age variable.

b. (Oktaviana, 2016) Relationship between Nutrition Knowledge and Sanitation Hygiene Behavior to Stunted Events for toddlers aged 7-24 months in Hargorejo Kulon Progo Village. This type of research is an observational cross-sectional design. Data on maternal nutrition knowledge and maternal sanitation were obtained by questionnaire interview. Child body length data obtained by anthropometric measurements were compared with the PB / U index. Independent Variable: Maternal Nutrition Knowledge and Maternal Hygiene Behavior. Bound Variable: Stunted Event. The results in this study showed that 
mothers with good knowledge amounted to $61.7 \%$. While mothers with good hygiene hygiene behavior were $80.9 \%$. So it can be concluded that there is a relationship between stunted events and sanitary hygiene behavior.

\subsection{Stunting}

In the handbook of the Secretariat of the Vice President of the Republic of Indonesia. The National Team for the Acceleration of Poverty Reduction (TNP2K) (Satriawan, 2018) states that stunting stunting illustrates the condition of failure to thrive in children due to malnutrition or chronic malnutrition during the period of growth and development that appears after children are 2 years old. This situation is represented by the height $\mathrm{z}$-score by age (TB / U) less than -2 standard deviations (SD) based on growth standards. Then referring (Sakti, Eka Satriani, 2018) stunting has an impact in reducing cognitive function and can cause low education and productivity, and of course this can decrease the quality of development in the Republic of Indonesia.

\subsection{Epidemiology}

(Vonaesch, et al., 2017) mentions that globally, one in four children (25\%) under five years of age experience stunting / growth delays and based on this, around $90 \%$ of these children live in Sub-Saharan Africa and Asia ( Levels and Trends in Child Malnutrition, WHO, UNICEF, World Bank, 2012). The situation of Short Toddler (Stunting) in Indonesia has the highest prevalence in the Southeast Asia / South-East Asia Regional (SEAR) is in Timor Leste and followed by Indonesia which is included in the third country with an average prevalence of stunting toddlers in Indonesia in 2005-2017 is 36.4\%. In 2010, around $26.7 \%$ of children in Asia and 26.7\% of children in Southeast Asia experienced stunting.

\subsection{Pathogenesis}

In the context of pathogenesis mechanisms of environmental contamination and stunting show that ingested microbes cause changes in intestinal structure and function (Mbuya \& Humphrey, 2016). Intestinal villous atrophy which results in a reduced ability of the intestine to absorb it maximally leading to digestive disorders and nutrient malabsorption. Chronic exposure causes: (i) malnutrition, (ii) suppresses growth hormones, so that bone growth and remodeling are inhibited and growth disturbance occurs, (iii) causes further damage to the intestinal mucosa. From this situation, the absorption of nutrients in the intestine is not optimal, so that nutrients that are very important for the growth and development of children become inadequate and the child experiences a growth disorder in a linear or stunting manner.

\subsection{Environmental Health}

As part of public health science, environmental health is a study that provides an overview of the dynamics of interactive relationships between population groups with various changes in environmental components that pose a threat that has the potential to disrupt public health or in other words environmental health coverage is all aspects of nature and the environment that are affect human health. The Definition of Environmental Health According to P. Halton Purdon (1971) in (Article Biofarma, 2014) is that Environmental Health is part of the basics of health for modern society, environmental health is an aspect of public health which includes all aspects of human health in relation to the environment. The aim is to maintain and improve the degree of public health at the highest level by modifying social factors, physical environmental factors, environmental characteristics and behaviors that can affect health. 
WHO states that environmental health is a condition in which environmental health relies to an ecological balance that must exist and man and his environment in order to ensure his health becomes. Environmental health is the realization of an ecological balance between humans and the environment that must exist, so that people become healthy and prosperous. So that according to WHO Environmental Health are: Those aspects of human health and disease that are determined by factors in the environment. It also refers to the theory and practice of assessing and controlling factors in the environment that can potentially affect health. Or if it is concluded "An ecological balance that must exist between humans and the environment in order to guarantee the healthy state of humans".

\subsection{Riverside Communities}

History shows that there is a close relationship between settlements and rivers, especially in the area of Central Kalimantan which already has a very close relationship between rivers in the formation and development of cities and their communities. From the time development of the people who live on the riverside community of the river, the community can make the river as a source of necessities of life and a source of income, both in terms of transportation, economic, social and cultural. With the interaction between the community and the river, river culture is formed. Culturally the people of Palangka Raya are very close to the river and difficult to separate from the river. Even from the existing history, the embryo of the City of Palangka Raya is a village on the riverside community of the river or originated from settlements along the riverside community. It is not wrong if the settlement on the river bank is one of the characteristics of the City of Palangka Raya. The Kahayan Riverside community are used for various activities, from settlement activities and other activities. With characteristic types of buildings on the riverside community of the Kahayan River are the floating and stage types. However, with the progress of the times there was a decline in some cultural activities of the river which was also followed by a decline in the function of the Kahayan River.

\section{Research Methods}

This type of research used in this study is qualitative, which serves to understand the meaning and elaborate the results of interactions with informants, the location of the research is in the Village of Pahandut, District of Pahandut. The city of Palangka Raya and chosen on the riverside community of the Kahayan river, this location is determined because there is potential for stunting and is also a representation of the problem formulation that has been determined. Data collection through observation and interviews. Observations were carried out in October 2019 to November 2019. The informant selection technique used simple random sampling, pregnant women, mothers with children under the age of 2 years and only young women selected.

The data used in this study are primary and secondary data. Primary data were obtained through interviews with toddlers, pregnant women and adolescents using depth and indept interview techniques. Secondary data were obtained from data obtained from the Pahandut Community Health Center.

Data analysis techniques use interactive analysis techniques, namely the process of data collection, data reduction, display, verification and conclusion drawing based on a predetermined formula, and given meaning by the researcher. 


\section{Discussion}

The river has a long flow as the main source of life by humans. Like bathing, washing, and so on as a livelihood. Rivers that flow and reach into each region make the river as a path to move from one place to another. The movement will form a structure of life that makes a settlement that initially the area was uninhabited, and became a fairly large settlement.

The philosophers of history say that history is a dialectic between continuity and discontinuity, succession between order and change, or the famous slogan of Soekarno history is a kind of revolutionary symphony of the attempt to break down and build, when connected with culture there will be a two-dimensional dialect of culture. According to Kleden, that culture is a dialect between calm and anxiety, between discovery and search, between integrity and disintegrity, between tradition and reform (Kleden, 1986).

The river is the identity of the people who live and live in Kalimantan, the river becomes a means of transportation in the transformation of the process of cultural formation for people in Central Kalimantan. Central Kalimantan consists of 13 Regencies and 1 City, the majority of which live along the riverside community of the river. there are around $20 \%$ of the total population living in the mainland without access to the river, and can be ascertained as a new residential area in the form of mobilization and transmigration (Nyahu, 2017).

Palangkaraya City starts from a village on the edge of the Kahayan River, called Pahandut Village. In this village, Dayak people depend their lives on the Kahayan river which divides the city of Palangka Raya. It was also in Pahandut Village that Sukarno first set foot in Central Kalimantan, precisely in July 1957. At that time Sukarno came to inaugurate the construction of the City of Palangka Raya, the capital of Central Kalimantan Province.

Settlements in the Pahandut region are influenced by natural conditions that are affected by nature, the pattern of community settlements on the riverside community of the Kahayan River, Pahandut Urban Village tends to be clustered, housing growth is unplanned and tends to be uncontrolled, dense and tends to become slum areas (Observation Results, 2019), even though Thus the people who live on the riverside community of the Kahayan river are divided into two groups, those who live in floating houses (lanting) and those who live on stilts (land) with the use of different water sources. Communities in lanting houses still use water sources originating from the river and houses on stilts use wells as a source of water (Interview Results, 2019).

For the ownership of toilet, the community in a stilt house has a toilet in their house, even though the sewage is still flowed directly into the river, the same as the lanting community (Interview Results, 2019). With the exception of the daray community, whose access is more than $20 \mathrm{~m}$ from the river mouth, all have septic tanks (Interview Results, 2019). An overview of community health conditions is presented in table 1.

Table 1. Health Conditions of River Bank Communities

\begin{tabular}{|c|c|c|c|}
\hline Community & Water Resources & Ownership of Toilet & Health Awareness \\
\hline Lanting House & $\begin{array}{l}\text { River water for bath, } \\
\text { wash, toilet } \\
\text { For cooking water is } \\
\text { deposited in a plastic } \\
\text { barrel and sprinkled } \\
\text { with alum }\end{array}$ & $\begin{array}{l}\text { toilet without a septic } \\
\text { tank }\end{array}$ & $\begin{array}{l}\text { 1. Wash hands without soap } \\
\text { 2. Household waste and } \\
\text { waste is disposed directly } \\
\text { into the river } \\
\text { 3. If sick to the } \\
\text { paramedics } \\
\text { nurse) }\end{array}$ \\
\hline
\end{tabular}




\begin{tabular}{|l|l|l|l|}
\hline $\begin{array}{l}\text { Panggung } \\
\text { House }\end{array}$ & $\begin{array}{l}\text { Water from the Drilling } \\
\text { Well. }\end{array}$ & $\begin{array}{l}\text { Toilet without septic } \\
\text { tanks } \\
\text { (for those close to the } \\
\text { river) and with septic } \\
\text { The water from the } \\
\text { wellbore still smells rust } \\
\text { so it must be deposited } \\
\text { in a plastic barrel. }\end{array}$ & $\begin{array}{l}\text { 1. Washing hands without } \\
\text { from the river mouth } \\
\text { soap }\end{array}$ \\
$\begin{array}{l}\text { 2. } \\
\text { rubbish are dumped } \\
\text { directly under the house } \\
\text { on stilts }\end{array}$ \\
$\begin{array}{l}\text { If it hurts to the } \\
\text { nearest spell (nearest } \\
\text { nurse) }\end{array}$
\end{tabular}

Source: Interview and Observation Results 2019

The condition of public health related to awareness of cleanliness and health based on the results of observations and interviews is quite low, this can be seen in common that both people who live on stilts and lanting houses both still have the habit of throwing trash directly in the river or under his house, and of course this can cause pollution to water sources, and even illness in the dry season.

The issue of stunting is a very urgent issue to be taken seriously because it involves the quality of Indonesia's human resources in the future and greatly influences the country's existence. At the policy level, the government has issued policies related to efforts to accelerate stunting prevention both through specific nutrition interventions and sensitive nutrition interventions (Izwardy, 2019). Diet is a risk factor that can increase the potential for stunting in the community. And people who live on the riverside community of the Kahayan river tend to have low access to the fulfillment of food nutrition, orientation to the quantity of food, and disease (Interview Results, 2019). In addition, secondary data shows that there are still 10 toddlers and toddlers with potential for stunting in the District of Pahandut (Pahandut Health Center Data, 2019).

\section{Conclusion}

Based on the explanation and discussion of the results of the study discussed, it can be concluded that the environmental health conditions of the people living on the riverside community of the Kahayan river are very bad, if referring to health standards, because there are no adequate sanitation facilities related to water management and disposal of solid and liquid waste, plus the habits of the people who still throw garbage directly into the river. The solution is to improve public health through collaboration of various parties, especially for the management of organic waste and plastic waste, changing the behavior patterns of disposing waste directly in the river. In addition, collaboration with agencies that deal with water issues and water management must be improved, so that it does not close the riverside community of the kahayan river area to become a clean and proper water area.

The potential for stunting for riverside community is quite large, because people who live on the riverside community of the Kahayan river tend to have low access to the fulfillment of food nutrition, orientation to the quantity of food, and disease. There should be further research and community empowerment by the Health Office related to the nutritional patterns of children, adolescents and pregnant women related to eating patterns based on quality and not based on quantity. 


\section{References}

Adisasmito, W. (2007). Sistem Kesehatan. Jakarta: PT Raja Grafindo Persada.

Artikel Biofarma. (2014). bumn.go.id. Retrieved from Pengertian Kesehatan Lingkungan: http://www.bumn.go.id/biofarma/berita/0-Pengertian-Kesehatan-Lingkungan

Balitbang Kemenkes RI. (2018). Laporan Nasional RISKESDAS. Jakarta: Balitbang Kemenkes RI.

Besral, M. A. (2014). Pola Asuh Gizi, Sanitasi Lingkungan dan Pemanfaatan Posyandu dengan kejadian stunting pada balita di Indonesia (analisis data RISKESDAS tahun 2010). Jakarta: Fakultas Kesehatan Masyarakat.

BPS. (2018). Kalimantan Tengah dalam Angka. Palangka Raya: BPS.

Fitri, R. 2020. E.Coli Analysis of Settlement without Slums in Deli River Watershed, Hamdan Sub-District, Medan Maimun. Budapest International Research and Critics Institute-Journal (BIRCI-Journal) (3): 1039-1053.

Hasibuan, S. M., Santosa, H., Asfriyati. 2020. Relationship of Family Income and Family Support with Maternal Reference in Pregnant Women in Pantai Cermin BEmONC, Langkat District, 2019. Budapest International Research and Critics Institute-Journal (BIRCI-Journal) (3): 486-493.

Izwardy, D. (2019). Kebijakan dan Strategi Penanggunalangan Stunting di Indonesia dipaparkan pada FGD skrining malnutrisi pada anak di Rumah Sakit di Hotel Luwansa 22 Februari 2019.

Kleden, I. (1986). Membangun Tradisi tanpa Sikap Tradisional Dilema Indonesia antara Kebudayaan dan Kebangsaan. Majalah Prisma Edisi 8.

Mbuya, M., \& Humphrey, J. (2016). Preventing Environmental Enteric Dysfunction through Improved Water, Sanitation and Hygiene: an Opportunity for Stunting Reduction in Developing Countries. Maternal \& Child Nutrition, 107-109.

Novita, W., Aulia, D., and Juanita. 2020. The Relationship between Geography Access and Utilization of Basic Emergency Neonatal Obstetric Services (PONED) in Hamparan Perak Health Center, Deli Serdang Regency in 2018. Budapest International Research and Critics Institute-Journal (BIRCI-Journal) (3): 674-681.

Nyahu, A. (2017, Agustus 14). Sungai bagi Orang Dayak Di Kalimantan Tengah. Retrieved November 12, 2019, from Wild Water Indonesia: http://wildwaterindonesia.org/sungaidayak-kalimantan/

Oktaviana, H. (2016). Hubungan Pengetahuan Gizi dan Perilaku Hygiene Sanitasi terhadap Kejadian Stunted pada Balita Usia 7-24 bulan di Desa Hargorejo Kulon Progo. Surakarta: Program Studi Ilmu Gizi Fakultas Ilmu Kesehatan. Universitas Muhammadiyah.

Republika. (2019, Maret 26). Harian Republika. Retrieved September 9, 2019, from Republika.co.id: https://nasional.republika.co.id/berita/nasional/daerah/poyjt1414/kasusemstunting-emdi-kalteng-terburuk-keempat-seindonesia

Sakti, Eka Satriani. (2018). SItuasi Balita Pendek (Stunting) di Indonesia. Jakarta: Pusat Data dan Informasi.

Satriawan, E. (2018). Penanganan Masalah Stunting di Indonesia. Bandar Lampung: Forum Ilmiah Tahunan Ikatan Ahli Kesehatan Masyarakat.

Trihono. (2015). Pendek (stunting) di Indonesia, Masalah dan Solusinya. Jakarta: Badan Penelitian dan Pengembangan Kesehatan.

Vonaesch, P., Tondeur, L., Breurec, S., Binh, L., Nguyen, L., \& Frank, T. (2017). Factors Associated with Stunting in Healthy Children Aged 5 years and Less Living in Bangui(RCA). (F. Wieringa, Ed.) PLoS ONE, 1-2. doi:https://doi.org/10.1371/journal.pone.0182363 